\title{
Analisis Kimia untuk Deteksi Kandungan Non-Halal pada Kosmetik
}

\author{
Maratul Mahdiyyah*, Norisca Aliza Putriana \\ Program Studi Sarjana Farmasi, Fakultas Farmasi, Universitas Padjadjaran \\ *email: maratulmahdiyyah@gmail.com \\ (Submit 9/8/2019, Revisi 20/8/2019, Diterima 21/8/2019)
}

\begin{abstract}
Abstrak
Peningkatan populasi muslim di dunia mengakibatkan adanya peningkatan terhadap konsumsi dan permintaan terhadap produk halal salah satunya adalah kosmetik. Kosmetik halal sudah bukan kata asing lagi bagi beberapa negara muslim, namun sayangnya masih banyak yang belum mengetahui definisi sebenarnya dari kosmetik halal. Masih banyak yang beranggapan produk kosmetik halal hanya yang mengandung babi dan alkohol saja. Review ini bertujuan untuk memberikan informasi mengenai kosmetik halal dan apa saja yang boleh terkandung di dalamnya serta analisis kimia yang digunakan untuk mendeteksi kandungan non halal dalam produk kosmetik.
\end{abstract}

Kata kunci: Kosmetik halal, kandungan non halal, analisis kimia

\section{Outline}

- Pendahuluan

- Definisi

- Bahan-bahan non-halal yang digunakan pada produk kosmetik

- Analisis kimia untuk otentikasi halal

- Metode review

- Hasil

- Pembahasan

- Kesimpulan

- Daftar Pustaka

\section{Pendahuluan}

Di zaman sekarang meskipun sebagai kebutuhan tersier, kosmetik permintaannya kian meningkat. Perkembangan ini sejalan dengan kemajuan ilmu pengetahuan dan teknologi serta dengan pengembangan produk. Keragaman produk konsumen meningkat dari tahun ke tahun. (Mursyidi A, 2013).

Dalam masyarakat modern, tujuan utama pemakaian kosmetik adalah untuk kebersihan pribadi, meningkatkan daya tarik melalui riasan, serta untuk meningkatkan harga diri dan meningkatkan ketenangan, melindungi kulit dan rambut dari kerusakan sinar ultraviolet, polutan, dan faktor lingkungan lainnya, serta mencegah penuaan. (Puziah et al., 2009). 
Dari perspektif muslim, penting mengetahui kandungan, bahan baku serta bagaimana cara pengolahan bahan baku tersebut yang ada pada produk kosmetik. Hal ini dikarenakan sesuai dengan syariat islam dimana umat muslim hanya boleh mengkonsumsi dan menggunakan produk-produk yang halal dan menghindari produk yang haram. (Mursyidi A, 2013).

Muslim adalah segmen konsumen terbesar, dengan miliaran konsumen termuda. Diketahui saat ini populasi muslim di dunia meningkat tiap tahunnya. Pada tahun 2013, diketahui terdapat $30 \%$ populasi muslim dari total populasi di dunia, dan bahkan diperkirakan akan terjadi peningkatan hingga 35\% pada tahun 2025 mendatang. Maka tidak salah jika permintaan kosmetik halal semakin meningkat dari tahun ke tahun (Esfahani and Shahnazari, 2013; Izberk-Bilgin and Nakata, 2016).

Terdapat penelitian yang menyatakan bahwa produk halal secara global mencapai angka USD 2,3 triliun dengan USD 230 miliar nya berasal dari kosmetik serta obatobatan. (Shafii and Wan Siti Khadijah, 2012).

\section{Definisi}

Istilah halal berarti "diizinkan untuk dikonsumsi dan digunakan oleh umat Islam, sedangkan haram adalah segala sesuatu yang melanggar hukum atau dilarang". Halal dan haram jelas ditunjukkan dalam hukum Islam dan dianggap sebagai masalah serius. Halal mencakup segala dan semua tahapan, mulai dari sumber bahan baku, distribusi produk akhir, hingga pengiriman ke konsumen. Tidak hanya makanan, istilah halal dapat mencakup semua barang habis pakai seperti obat-obatan, kosmetik, produk perawatan pribadi, perlengkapan mandi, dll. (Che Man and Sazili, 2010)

Kosmetik menjadi salah satu diantara produk yang perlu dilihat keseluruhan sistem manajemennya apakah sudah sesuai dengan halal atau tidak. Kosmetik halal adalah produk yang tidak boleh memiliki bagian manusia atau bahan apa pun atau mengandung hewan apa pun yang dilarang untuk Muslim dan harus disembelih sesuai dengan hukum syariah; tidak ada organisme hasil rekayasa genetika yang dinyatakan sebagai najis; tidak ada minuman alkohol (khamar); tidak ada kontaminasi dari najis selama persiapan, pemrosesan, pembuatan dan penyimpanan; dan aman bagi konsumen. Selain itu, segala penggunaan lemak hewani dan pengujiannya, bahan kimia berbahaya dan bahan lainnya dianggap tidak dapat digunakan oleh umat muslim.(Kaur, Osman and Maziha, 2014; Aoun and Tournois, 2015).

\section{Bahan-bahan non-halal yang digunakan pada produk kosmetik}

Istilah halal tidak hanya menjadi dasar bagi konsumen muslim dalam memilih produk namun juga menjadi suatu label yang mengisyaratkan produk tersebut aman serta murni karena tidak mengandung bahan-bahan haram. Namun, konsumen muslim saat ini masih belum tahu banyak mengenai kosmetik halal. Kesadaran terhadap isu kosmetik halal masih minim dibandingkan dengan produk makanan halal. 
Kebanyakan masih berfikir bahwa produk yang haram hanya mengandung unsur babi serta alkohol. Padahal sebenernya masih banyak kandungan lain selain babi dan alcohol yang dapat dikatakan haram, serta produk yang haram juga bisa dikarenakan proses pembuatan, pengemasan, serta pengirimannya.(Ali, Fairol Halim and Norzieiriani Ahmad, 2016; Mohezar, Suhaiza and Zainorfarah, 2018)

Tidak hanya produk babi beserta turunannya dan alcohol yang dikategorikan haram. Barang-barang non-halal yang digunakan dalam pembuatan kosmetik dapat diklasifikasikan berdasarkan asalnya, yaitu manusia dan hewan. Dalam hal pembuatan kosmetik, masalah yang sering muncul berkaitan dengan status "najs" (tidak murni) dari bahan-bahan tersebut. Beberapa dari bahan-bahan tersebut adalah sebagai berikut:

1. Keratin, bahan kimia yang diperoleh dari rambut manusia dan digunakan sebagai zat pewarna rambut

2. Albumin, berasal dari serum manusia dan digunakan sebagai pelarut untuk melarutkan bahan aktif dalam formulasi kosmetik

3. Ekstrak plasenta, dibuat dengan ekstraksi plasenta manusia di bawah prosedur tertentu. Ekstrak ini diyakini sebagai preparasi kosmetik pilihan untuk produk antipenuaan dan perawatan kulit.

4. Asam hialuronat, bahan kimia yang diperoleh dari rahim dan biasa digunakan untuk kosmetik pemutih dan perawatan kulit.

(Mursyidi A, 2013)

Beberapa bahan lain yang digunakan juga diantaranya lemak dan asam lemak, yang banyak digunakan dalam produk kosmetik seperti sampo, sabun, lotion tubuh, dan lipstik, dapat berasal dari sumber hewani. Kolagen (protein berserat yang berasal dari jaringan hewan) dan plasenta digunakan dalam pengobatan anti-penuaan. Karbamid, zat yang dikeluarkan dari urin, digunakan dalam deodoran, pewarnaan rambut, krim tangan, lotion, dan sampo. Allantoin, metabolit asam urat dari mamalia, sering digunakan dalam krim dan lotion.(Shafii and Wan Siti Khadijah, 2012).

\section{Analisis kimia untuk otentikasi halal}

Deteksi bahan-bahan non-halal untuk menentukan status halal dari setiap produk kosmetik dan perawatan pribadi penting dilakukan untuk menjaga integritas produkproduk halal dan kepercayaan konsumen. Dalam beberapa tahun terakhir, metode deteksi untuk bahan-bahan non-halal telah dikembangkan secara luas untuk membantu otoritas keagamaan dalam memverifikasi kepatuhan halal dan untuk mendeteksi keberadaan bahan-bahan non-halal. Untuk penilaian halal dan haram, metode analisis pada dasarnya difokuskan pada analisis kualitatif (identifikasi) daripada analisis kuantitatif. Ini semata-mata karena status haram sangat ditentukan oleh jenis materi daripada kuantitas. Beberapa teknik pendeteksian seperti Spektroskopi Fourier Transform Infrared (FTIR), kromatografi gas dua dimensi yang komprehensif dihiphenasi dengan spektrometri massa waktu terbang (GCxGC-TOF-MS) dan kromatografi gas-spektrometri massa (GCMS) telah dikembangkan untuk mendeteksi gelatin, alkohol, lemak, dan minyak dalam produk kosmetik (Puziah et al., 2009; Rohman and Che Man, 2009; Mursyidi A, 2013). 
Tujuan dari pembuatan review ini yaitu untuk memberikan gambaran mengenai produk kosmetik halal dan bagaimana analisis yang digunakan untuk mendeteksi bahan-bahan non-halal yang berada di kosmetik.

\section{Metode Review}

Metode yang digunakan pada penulisan review ini menggunakan studi literatur dari dalam negeri maupun luar negeri yang diambil dari beberapa situs pencarian jurnal online yang berhubungan dengan kosmetik halal, skin care halal, serta deteksi dan analisis bahan-bahan non halal pada kosmetik dan perawatan tubuh. Jurnal yang digunakan sebagai referensi dalam pembuatan review ini, memiliki rentang publikasi 10 tahun terakhir yaitu dari tahun 2009 sampai 2019.

\section{Hasil}

Beberapa bahan-bahan non-halal telah ditemukan di sediaan kosmetik maupun perawatan tubuh. Berikut beberapa artikel terkait yang membahas mengenai analisis untuk mendeteksi bahan-bahan tersebut menggunakan sampel kosmetik.

Tabel 1. Analisis Kimia untuk Mendeteksi Kandungan Non Halal

\begin{tabular}{|c|c|c|c|}
\hline JUDUL & PENULIS (TAHUN) & BAHAN NON-HALAL & ANALISIS KIMIA \\
\hline $\begin{array}{l}\text { Potential use of Fourier transtorm } \\
\text { infrared spectroscopy for differentiation } \\
\text { of bovine and porcine gelatins }\end{array}$ & Hashim, et al (2010) & $\begin{array}{l}\text { Gelatin sapi dan gelatin } \\
\text { babi }\end{array}$ & $\begin{array}{l}\text { menggunakan Fourier transform } \\
\text { infrared (FTIR) dikombinasi dengan } \\
\text { attenuated total reflectance (ATR) }\end{array}$ \\
\hline $\begin{array}{l}\text { Quantitative Analysis of Lard in Cosmetic } \\
\text { Lotion Formulation } \\
\text { Using FTIR Spectroscopy and Partial Least } \\
\text { Square Calibration }\end{array}$ & Lukitaningsih, et al. (2012) & Lemak babi & $\begin{array}{l}\text { Menggunakan Spektroskopi Fourier } \\
\text { transform infrared (FTIR) dikombinasi } \\
\text { dengan } \\
\text { chemometrics of partial least squares } \\
\text { (PLS) }\end{array}$ \\
\hline $\begin{array}{l}\text { Analysis of Lard in Lipstick Formulation } \\
\text { Using FTIR } \\
\text { Spectroscopy and Multivariate } \\
\text { Calibration: } \\
\text { A Comparison of Three Extraction } \\
\text { Methods }\end{array}$ & Waskitho, et al. (2016) & Lemak babi & $\begin{array}{l}\text { Menggunakan Spektroskopi Fourier } \\
\text { transform infrared (FTIR) }\end{array}$ \\
\hline $\begin{array}{l}\text { Detection of Porcine Adulteration in } \\
\text { Cosmetic Cream } \\
\text { TaqMan Probe Real-Time Polymerase } \\
\text { Chain Reaction }\end{array}$ & Mustafa et al. (2018) & Babi & $\begin{array}{l}\text { Menggunakan PCR Real-Time Probe } \\
\text { TaqMan. }\end{array}$ \\
\hline $\begin{array}{l}\text { Analysis of Lard in Cream Cosmetics } \\
\text { Formulations } \\
\text { Using FT-IR Spectroscopy and } \\
\text { Chemometrics }\end{array}$ & Rohman, et al. (2011) & Lemak babi & $\begin{array}{l}\text { Menggunakan Spectroskopi FT-IR dan } \\
\text { Kemometrik }\end{array}$ \\
\hline $\begin{array}{l}\text { Quantification of Lard in the Mixture with } \\
\text { Olive Oil in Cream Cosmetics Based on } \\
\text { FTIR Spectra and Chemometrics for Halal } \\
\text { Authentication }\end{array}$ & Rohman et al. (2014) & Lemak Babi & $\begin{array}{l}\text { Menggunakan Spektroskopi FTIR dan } \\
\text { Kemometrik }\end{array}$ \\
\hline $\begin{array}{l}\text { Effect of DNA extraction methods on the } \\
\text { detection of porcine } \\
\text { ingredients in halal cosmetics using real- } \\
\text { time PCR }\end{array}$ & Kim et al. (2018) & Babi & Menggunakan Real-Time PCR \\
\hline $\begin{array}{l}\text { Analysis of Lard's Aroma by an Electronic } \\
\text { Nose for Rapid Halal } \\
\text { Authentication }\end{array}$ & Nurjuliana et al. (2010) & Lemak Babi & $\begin{array}{l}\text { Menggunakan Electric nose kemudian } \\
\text { hasilnya akan terlihat dalam bentuk } \\
\text { VaporPrintTM. }\end{array}$ \\
\hline
\end{tabular}


(Hashim et al., 2010) telah melakukan pembuktian untuk membedakan gelatin dari babi dan gelatin dari sapi menggunakan spektroskopi FTIR. Dari penelitian ini diketahui Spektroskopi FTIR dapat digunakan untuk klasifikasi gelatin.

(Lukitaningsih et al., 2012) menggunakan PLS dan PCA untuk kuantifikasi dan klasifikasi lemak babi dalam kosmetik lotion. Sampel lemak dalam lotion diekstraksi dengan hidrolisis pengemulsi menggunakan $\mathrm{HCl}$ pekat, pemisahan fraksi lipid menggunakan kloroform, dan menghilangkan kloroform untuk mendapatkan fraksi lipid. Ekstrak lipid yang diperoleh selanjutnya ditentukan dengan menggunakan spektrofotometer FTIR. Jumlah gelombang yang dioptimalkan dari $1.200-1.000 \mathrm{~cm}-1$ dipilih dan berhasil diterapkan untuk kuantifikasi lemak babi menggunakan PLS dan klasifikasi menggunakan PCA.

(Waskitho et al., 2016) telah membuktikan bahwa Spektroskopi FTIR dikombinasikan dengan analisis multivariat dari analisis komponen utama dan kuadrat terkecil parsial dapat digunakan untuk menganalisis keberadaan lemak babi dan turunannya dalam formulasi lipstik. Di antara metode ekstraksi yang digunakan, Bligh \& Dryer lebih disukai untuk klasifikasi dan kuantifikasi lemak babi dalam sampel kosmetik.

(Mustafa et al., 2018) menggunakan real-time PCR untuk mendeteksi DNA babi pada krim yang dipalsukan. Studi ini menunjukkan bahwa, krim yang diformulasikan berpotensi memiliki DNA genomik yang dapat diekstraksikan dari sana.

(Rohman, Abdul; Che Man, 2011) telah membuktikan analisis menggunakan spektroskopi FTIR yang dikombinasikan dengan PLS dan analisis diskriminan untuk kuantitatif dan diskriminasi lemak babi dalam campuran dengan minyak kelapa murni (VCO) dapat digunakan pada formulasi kosmetik krim. Hasil ini juga dapat diperluas ke berbagai jenis sediaan kosmetik topikal yang menggunakan minyak sebagai dasar dalam formulasi mereka.

(Rohman et al., 2014) telah membuktikan Spektroskopi FTIR yang dikombinasi dengan partial least square (PLS) dapat digunakan untuk mengukur kadar lemak babi dalam campuran dengan olive oil dalam krim kosmetik.

(Kim et al., 2018) menggunakan PCR real-time untuk mendeteksi DNA babi dalam kosmetik. Hasil yang didapat diketahui uji PCR real-time berdasarkan gen mitokondria ndh5 memfasilitasi deteksi jumlah jejak DNA template babi di kosmetik. Studi ini juga menunjukkan bahwa ekstraksi DNA babi dari kosmetik kemungkinan besar tergantung pada jenis kosmetik. Uji PCR real-time khusus-babi ini juga berlaku untuk deteksi bahan babi yang tersembunyi dalam produk makanan atau bisa juga digunakan untuk identifikasi kecurangan makanan.

(Nurjuliana, Che Man and Mat Hashim, 2011) di dalam penelitiannya, menggunakan electric nose sebagai teknik baru yang cepat prosesnya untuk menganalisis aroma berbagai lemak tubuh hewan. Karya ini jelas menunjukkan potensi electric nose sebagai teknik profil aroma yang cepat. Studi ini juga menunjukkan bahwa metode yang dikembangkan memiliki potensi untuk implementasi praktis dalam otentikasi halal. 


\section{Pembahasan}

Dari beberapa penelitian tersebut penggunaan FTIR menjadi pilihan yang paling sering digunakan dalam mendeteksi adanya bahan-bahan non-halal pada produk kosmetik. Dalam bidang analisis, spektroskopi FTIR memberikan pilihan yang sangat efektif. FTIR adalah teknik yang cepat, sensitive, tidak merusak, dan tidak perlu atau sederhana dalam persiapan sampel selain itu juga dianggap sebagai green analytical technique karena penggunaan reagen kimia dan pelarut yang rendah dalam operasinya. (Blanco et al., 2007).

Penelitian sebelumnya menunjukkan bahwa spektroskopi FTIR dapat digunakan sebagai metode untuk analisis lemak babi, terutama dalam sistem makanan seperti pada kue dan produk cokelat, atau campuran lemak babi dengan lemak dan minyak lainnya. Serta ada pula yang menggunakan spektroskopi FTIR untuk mengkarakterisasi lemak babi dan lemak dan minyak lainnya yang dapat dimakan. Hampir semua penelitian yang dilakukan sebelumnya didasarkan pada makanan atau produk makanan. Pada kosmetik, spektroskopi FTIR telah digunakan untuk penentuan minyak kelapa murni sebagai sistem pengemulsi pada formulasi krim. (Che Man et al., 2005; Syahariza et al., 2005; Rohman, Che Man and Sismindari, 2009; Che Man, Rohman and Mansor, 2011)

Langkah-langkah analisis yang digunakan di setiap penelitian meliputi preparasi kosmetik menggunakan lemak babi sebagai salah satu komponen, ekstraksi lemak babi dari sampel kosmetik menggunakan metode ekstraksi seperti metode Soxhlet, Bligh, dan Dyer atau Folch, akuisisi spektrum FTIR, kalibrasi pengembangan, dan model validasi, evaluasi model, dan akhirnya analisis lemak babi dalam sampel (Rohman and Salamah, 2018).

Salah satu faktor yang berkontribusi terhadap keberhasilan spektroskopi molekuler adalah pengembangan perangkat lunak kemometrik yang digunakan untuk pengolahan data, terutama untuk spektrum yang kompleks dan tumpang tindih. Menurut International Chemometrics Society (ICS), kemometrik didefinisikan sebagai ilmu yang menghubungkan pengukuran kimia yang dibuat pada sistem kimia dengan properti yang diiinginkan (seperti konsentrasi) melalui penerapan metode matematika atau statistik. (Gemperline, 2006; Bosque-Sendra et al., 2012).

Untuk analisis otentikasi halal, kemometrik yang digunakan bersamaan dengn data spektra pada dasarnya dimaksudkan untuk dua tujuan utama, yaitu tujuan kualitatif dengan membuat pengenalan pola (klasifikasi dan diskriminasi) dan tujuan kuantitatif dengan menerapkan model kalibrasi multivariate. (Miller, 2010).

Dari segala keuntungan FTIR, metode ini memiliki keterbatasan pada deteksi lemak babi nanoteknologi komersial produk kosmetik. Karena spektroskopi FTIR hanya dapat digunakan untuk formulasi tertentu. (Rohman, Abdul; Che Man, 2011). 
Polymerase Chain Reaction (PCR) menggunakan pendekatan berbasis DNA yang dikenal spesifik, dapat direproduksi, sensitif, serta dengan waktu pemrosesan yang cepat dan biaya yang rendah. (Nooratiny et al., 2013). Kemampuannya untuk memperkuat urutan yang ditargetkan dapat membantu dalam mendeteksi wilayah minat DNA. Selain itu, Real-time PCR adalah metodologi PCR lain yang diterapkan yang menyediakan deteksi kecepatan dan deteksi yang berdasarkan waktu nyata karena metode ini menggunakan sistem pendeteksian fluoresensi. Sinyal fluoresensi ini digunakan untuk mengukur jumlah DNA dalam sampel. (Mustafa et al., 2018).

E-nose atau electric nose, teknologi ini didasarkan pada pengembangan kimia bau di mana setiap bau terkait dengan keberadaan senyawa tertentu. Instrumen ini terdiri dari berbagai sensor kimia elektronik dan sistem pengenalan pola yang sesuai, mampu mengenali bau yang sederhana atau kompleks. Selain itu, E-nose juga bisa diterapkan untuk mengidentifikasi minyak yang tercemar oleh karakteristik penciuman 2 dimensi yang disebut VapourPrintTM. Metode E-nose adalah pilihan alternatif yang menarik yang menawarkan pengoperasian yang lebih mudah dengan hasil yang andal yang dapat dicapai hanya dalam beberapa menit. Oleh karena itu, metode ini berguna untuk identifikasi cepat pemalsuan lemak babi dalam konsentrasi yang relatif rendah (1\%). (Nurjuliana et al., 2011; Nurjuliana, Che Man and Mat Hashim, 2011).

Hingga saat ini penelitian yang secara khusus dilakukan untuk mendeteksi bahanbahan non-halal pada produk kosmetik tidak sebanyak pada produk makanan atau obat-obatan. Dari beberapa sumber literatur yang didapat, hampir semua mendeteksi bahan-bahan yang berasal dari babi, seperti lemak babi dan turunannya. Namun, masih sangat jarang yang membahas tentang bahan-bahan non-halal lain seperti plasenta, lanolin, albumin, dan sebagainya. Hal ini bisa dikaitkan dengan tingkat kesadaran dan pengetahuan yang dimiliki masyarakat muslim mengenai apa saja yang masuk pada kriteria kosmetik halal. Sebuah survei yang dilakukan oleh KasihDia Consulting tentang kosmetik halal menyatakan bahwa tingkat kesadaran di kalangan umat Islam masih rendah. Hal ini juga terjadi di beberapa Negara lain seperti Uni Emirat Arab dan Arab Saudi dengan sedikit pengetahuan tentang produk-produk. (Hajipour et al., 2015)

Ada beberapa alternatif yang dapat digunakan untuk menggantikan bahan-bahan nonhalal seperti contohnnya, minyak nabati dapat digunakan sebagai sumber asam lemak dan kolagen dapat diperoleh dari protein kedelai. Komite Teknis UEA untuk halal merekomendasikan hal-hal berikut untuk bahan kosmetik halal:

1. Semua jenis perairan diizinkan dengan pengecualian (1) air daur ulang (air limbah), dan (2) air mutanajs.

2. Semua jenis tanah diizinkan dengan pengecualian tanah yang diambil dari kuburan, peternakan, dan area pembuangan.

3. Hewan dan tumbuhan yang memenuhi persyaratan Konvensi Perdagangan Internasional untuk Spesies Flora dan Fauna Liar yang Terancam Punah tidak akan digunakan.

4. Penggunaan agro-bahan olahan secara fisik atau kimia tunduk pada ketentuan sebagai berikut: (1) sumber bahan agro dan instrumen, peralatan, atau mesin yang digunakan adalah halal dan (2) tidak ada yang menjadi mutanaj selama tahap pemrosesan. 
5. Alkohol seperti etanol dan alkohol lainnya dan turunannya diizinkan selama mereka bukan minuman beralkohol (khamar).

6. Transgenik atau zat yang mengandung transgenik diizinkan asalkan tidak mengandung gen manusia atau gen yang diperoleh dari sumber hewan terlarang, dan / atau hewan terlarang tidak digunakan sebagai inang.

Penggunaan produk mikroba tergantung pada media pertumbuhan. Jika media pertumbuhannya halal atau berutang asal ke sumber halal, maka mikroba yang tumbuh di media ini halal (Sugibayashi, 2017)

\section{Kesimpulan}

Beberapa penelitian telah membuktikan adanya kandungan bahan-bahan non-halal seperti gelatin dan lemak babi pada produk kosmetik dengan beberapa analisis seperti FTIR, Real-time PCR, serta E-nose.

\section{Daftar Pustaka}

Ali, S., Fairol Halim and Norzieiriani Ahmad (2016) 'The State of Halal Cosmetic Research on Consumer Behavior: A Systematic Review of the Literature and Future Research Directions', Journal of Marketing Management and Consumer Behavior.

Aoun, I. and Tournois, L. (2015) 'Building holistic brands: An exploratory study of halal cosmetics', Journal of Islamic Marketing. doi: 10.1108/JIMA-05-2014-0035.

Blanco, M. et al. (2007) 'Quality control of cosmetic mixtures by NIR spectroscopy', Analytical and Bioanalytical Chemistry. doi: 10.1007/s00216-007-1541-3.

Bosque-Sendra, J. M. et al. (2012) 'Combining chromatography and chemometrics for the characterization and authentication of fats and oils from triacylglycerol compositional data-A review', Analytica Chimica Acta. doi: 10.1016/j.aca.2012.02.041.

Che Man, Y. B. et al. (2005) 'Analysis of potential lard adulteration in chocolate and chocolate products using Fourier transform infrared spectroscopy', Food Chemistry. doi: 10.1016/j.foodchem.2004.05.029.

Che Man, Y. B., Rohman, A. and Mansor, T. S. T. (2011) 'Differentiation of lard from other edible fats and oils by means of Fourier transform infrared spectroscopy and chemometrics', JAOCS, Journal of the American Oil Chemists' Society. doi: $10.1007 / \mathrm{s} 11746-010-1659-\mathrm{x}$.

Che Man, Y. B. and Sazili, A. Q. (2010) 'Food Production from the Halal Perspective', in Handbook of Poultry Science and Technology. doi: 10.1002/9780470504451.ch11.

Esfahani, A. N. and Shahnazari, A. (2013) 'Designing Halal and Pure Food Model by Emphasizing Consumer Behavior Management', J. Basic. Appl. Sci. Res. 
Gemperline, P. (2006) 'Practical Guide To Chemometrics, Second Edition', Book (Chemo). doi: 10.1201/9781420018301.

Hajipour, B. et al. (2015) 'Raising Halal Cosmetic Awareness among the respective Consumers', International Journal of Academic Research in Business and Social Sciences. doi: 10.6007/ijarbss/v5-i7/1745.

Hashim, D. M. et al. (2010) 'Potential use of Fourier transform infrared spectroscopy for differentiation of bovine and porcine gelatins', Food Chemistry. doi: 10.1016/j.foodchem.2009.05.049.

Izberk-Bilgin, E. and Nakata, C. C. (2016) 'A new look at faith-based marketing: The global halal market', Business Horizons. doi: 10.1016/j.bushor.2016.01.005.

Kaur, K., Osman, S. and Maziha, S. (2014) 'Predicting working women purchasing behaviour of Malaysian Halal cosmetic products by using theory of planned behaviour', International Academic Research Journal of Business and Management. doi: http://dx.doi.org/10.1016/j.ijheatmasstransfer.2015.04.065.

Kim, Y. S. et al. (2018) 'Effect of DNA extraction methods on the detection of porcine ingredients in halal cosmetics using real-time PCR', Applied Biological Chemistry. doi: 10.1007/s13765-018-0389-x.

Lukitaningsih, E. et al. (2012) 'Quantitative analysis of lard in cosmetic lotion formulation using FTIR spectroscopy and partial least square calibration', JAOCS, Journal of the American Oil Chemists' Society. doi: 10.1007/s11746-012-2052-8.

Miller, J. M. and J. (2010) 'Statistics and Chemometrics for Analytical Chemistry', Technometrics. doi: 10.1198/tech.2004.s248.

Mohezar, S., Suhaiza, Z. and Zainorfarah, Z. (2018) 'Halal Cosmetics Adoption Among Young Muslim Consumers in Malaysia: Religiosity Concern', Global Journal Al Thaqafah. doi: 10.7187/gjat10220160601.

Mursyidi A (2013) 'The role of chemical analysis in the halal authentication of food and pharmaceutical products', Journal of Food and Pharmaceutical Sciences. doi: $10.14499 / j f p s$.

Mustafa, S. et al. (2018) 'Detection of Porcine Adulteration in Cosmetic Cream Formulation via TaqMan Probe Real-Time Polymerase Chain', 7, pp. 112-115.

Nooratiny, I. et al. (2013) 'DNA extraction from ghee and beef species identification using polymerase chain reaction (PCR) assay', International Food Research Journal.

Nurjuliana, M. et al. (2011) 'Rapid identification of pork for halal authentication using the electronic nose and gas chromatography mass spectrometer with headspace analyzer', Meat Science. doi: 10.1016/j.meatsci.2011.02.022. 
Nurjuliana, M., Che Man, Y. B. and Mat Hashim, D. (2011) 'Analysis of lard's aroma by an electronic nose for rapid Halal authentication', JAOCS, Journal of the American Oil Chemists' Society. doi: 10.1007/s11746-010-1655-1.

Puziah, H. et al. (2009) 'A cosmetic analysis in compliance with the legislative requirements, halal and quality control', Malaysian Journal of Chemistry, 11(1), pp. 8187. Available at: http://scholar.google.com/scholar?hl=en\&btnG=Search\&q=intitle:A+Cosmetic+Analysis+ in+Compliance+with+the+Legislative+Requirements+,+Halal+and+Quality+Control\#0.

Rohman, Abdul; Che Man, Y. B. (2011) 'Analysis of lard in cream cosmetics formulations using ft-ir spectroscopy and chemometrics', Middle-East Journal of Scientific Research.

Rohman, A. et al. (2014) 'Quantification of lard in the mixture with olive oil in cream cosmetics based on FTIR spectra and chemometrics for Halal authentication', Jurnal Teknologi (Sciences and Engineering). doi: 10.11113/jt.v69.2062.

Rohman, A. and Che Man, Y. B. (2009) 'Analysis of cod-liver oil adulteration using fourier transform infrared (FTIR) spectroscopy', JAOCS, Journal of the American Oil Chemists' Society. doi: 10.1007/s11746-009-1453-9.

Rohman, A., Che Man, Y. B. and Sismindari (2009) 'Quantitative analysis of virgin coconut oil in cream cosmetics preparations using fourier transform infrared (FTIR) spectroscopy', Pakistan Journal of Pharmaceutical Sciences.

Rohman, A. and Salamah, N. (2018) 'The employment of spectroscopic techniques coupled with chemometrics for authentication analysis of halal pharmaceuticals', Journal of Applied Pharmaceutical Science. doi: 10.7324/JAPS.2018.81009.

Shafii, Z. and Wan Siti Khadijah, W. M. N. (2012) 'Halal traceability framework for halal food production', World Applied Sciences Journal.

Sugibayashi, K. (2017) 'Skin permeation and disposition of therapeutic and cosmeceutical compounds', Skin Permeation and Disposition of Therapeutic and Cosmeceutical Compounds, pp. 1-428. doi: 10.1007/978-4-431-56526-0.

Syahariza, Z. A. et al. (2005) 'Detection of lard adulteration in cake formulation by Fourier transform infrared (FTIR) spectroscopy', Food Chemistry. doi: 10.1016/j.foodchem.2004.10.039.

Waskitho, D. et al. (2016) 'Analysis of Lard in Lipstick Formulation Using FTIR Spectroscopy and Multivariate Calibration: A Comparison of Three Extraction Methods', Journal of Oleo Science. doi: 10.5650/jos.ess15294. 